\title{
Emergency nursing: the Institute of Hygiene's performance during the brazilian civil war of 1932
}

Enfermagem de emergência: a atuação do Instituto de Higiene durante a guerra civil brasileira de 1932 Enfermería de Emergencia: la actuación del Instituto de Higiene durante la guerra civil brasileña de 1932

\author{
Maria Cristina da Costa Marques ${ }^{1}$ (iD \\ Danilo Fernandes Brasileiro ${ }^{1}$ (ic) \\ Felipe Daiko Fraga ${ }^{1}$ (IC
}

1. Universidade de São Paulo. São Paulo, SP, Brasil
Corresponding author:

Maria Cristina da Costa Marques.

E-mail:mcmarques@usp.br.

Submitted on 09/28/2018.

Accepted on 12/27/2018.

DOI: 10.1590/2177-9465-EAN-2018-0290

\section{Abstract}

Objectives: to analyze and describe the São Paulo Institute of Hygiene's performance, now the School of Public Health of the Universidade de São Paulo, in the training of emergency nurses during the Brazilian Civil War. Method: descriptive, historicaldocumentary study. Results: ministered from July 13 to August 31, 1932 to 383 students, in five classes, with an average of ten days of class. The discipline First Aid to the Wounded of Trenches is highlighted and was ministered by the nurse Iracema Niebler. At the end of the course, the students graduated and made up the List of Nurses of the Barracks Battalion of São Paulo. Conclusion and implications for the practice: the Institute of Hygiene's performance in the training of civilians in emergency/war nurses revealed the institutional political alignment with the revolutionary movement of 1932, as well as the historical rescue of one of the first initiatives to train hands-on nurses assist in emergency situations during the most emblematic brazilian Civil War of 1932.

Keywords: Public Health; Wars and Armed Conflicts; Training; Emergency Nursing.

\section{Resumo}

Objetivos: analisar e drescrever a atuação do Instituto de Higiene de São Paulo, atual Faculdade de Saúde Pública da USP na formação de enfermeiros de emergência durante a Guerra Civil brasileira de 1932. Método: estudo descritivo, históricodocumental. Resultados: ministrado entre 13 de julho a 31 de agosto de 1932, para 383 alunas, em cinco turmas, com média de dez dias de aula. Destaca-se a disciplina Primeiros Socorros aos Feridos de Trincheiras, ministrada pela enfermeira Iracema Niebler. Ao fim do curso, os alunos foram diplomados e compuseram a Lista de Enfermeiras do Quartel do Batalhão Paulista. Conclusão e implicações para a prática: a atuação do Instituto de Higiene na formação de civis em enfermeiros de emergência/ guerra revelou o alinhamento político institucional com o movimento revolucionário de 1932, como também possibilitou o resgate histórico de uma das primeiras iniciativas de capacitação de enfermeiros práticos para assistência em situações de emergência, durante a mais emblemática Guerra Civil brasileira.

Palavras-chave: Saúde Pública; Guerras e Conflitos Armados; Capacitação; Enfermagem em Emergência.

\section{REsumen}

Objetivos: analizar y describir la actuación del Instituto de Higiene de São Paulo, actual Facultad de Salud Pública de la USP, en la formación de enfermeros de emergencia durante la Guerra Civil de 1932. Método: estudio descriptivo, histórico-documental. Resultados: ministrado entre el 13 de julio al 31 de agosto 1932, para 383 alumnas, en cinco grupos, con media de diez días de clases. Se destaca la disciplina Primeros Auxilios a los Heridos de Trincheras, ministrada por la enfermera Iracema Niebler. A final del curso, los alumnos eran diplomados y componían la Lista de Enfermeras del Cuartel del Batallón Paulista. Conclusión e implicaciones para la práctica: la actuación del Instituto de Higiene en la formación de civiles en enfermeros de emergencia/ guerra reveló la alineación política institucional con el movimiento revolucionario de 1932, como también posibilitó el rescate histórico de una de las primeras iniciativas de capacitación de enfermeros prácticos para asistencia en situaciones de emergencia durante la más emblemática Guerra Civil brasileña de 1932

Palabras clave: Salud Pública; Guerras y Conflitos Armados; Formación; Enfermería em Emergencia. 


\section{INTRODUCTION}

The Brazilian Civil War, or "Constitutionalist Revolution of 1932", arose from the opposition movement of São Paulo State to the "Temporary" Government of Getúlio Vargas"1,2. There was conflict due to the need to retake the political autonomy of São Paulo and the desire for a new Constitution and elections for president, since Paulistas (population who lives in São Paulo State) considered the Government of Getúlio Vargas illegal ${ }^{3,4}$.

Amidst the turmoil in the relations of power struggle, the regionalismo paulista or paulistanidade (way of acting or acting coming from the formation and development of the São Paulo regionalism, its reflexes in schools, civic parties, etc.) coming from cultural and political elites of Sao Paulo, as opposed to brasilidade (characteristic or peculiarity of what or who is Brazilian; nature of what or what is Brazilian), was gradually disseminated among the majority of the population. Clauses for autonomy were chanted and justified by the conception that São Paulo was the "locomotive" of the country and should not surrender to the impositions of the Government of Getúlio Vargas ${ }^{1,5}$.

On July 9, 1932, the armed conflict against the Federal Government began and lasted until October 2 of the same year (85 days). This event was considered by many to be the worst "Civil War in the country"1,6, with about 60,000 São Paulo fighters (mostly volunteers) against 350,000 of the Provisional Government (navy, army, state public forces, etc.). There were five main fighting fronts (Vale do Paraíba, Mineira, Mato Grosso, Sul or Paraná and Litoral), causing hundreds of wounded, with 600 to 830 dead combatants, a number superior to the fatal victims of the Brazilian squads that fought in World War II?.

The majority of combatants of São Paulo volunteered, influenced by a persuasive strategy of recruitment that mobilized the population. There were several actions that expressed the politico-social dimension of care as an essential strategy for defense and protection of São Paulo forces. Among them, the training of hands-on nurses by the Cruz Azul of São Paulo (freely translated as Blue Cross, a charitable and philanthropic institution located in the city of São Paulo) ${ }^{8}$ the training of Black Legion Nurses by the Brazilian Red Cross ${ }^{9,10}$, and the São Paulo Institute of Hygiene. Thus, the Emergency Nursing Course was promoted, also known as War Nurses Course ${ }^{11}$.

The Institute of Hygiene, which acted in promoting the aforementioned course, before the Brazilian Civil War, faced questions related to its affirmation as an institution of education and that persisted in the postwar period ${ }^{12}$. It was founded in 1918 and linked to the "Chair of Hygiene" and Anatomy of the Faculdade de Medicina de São Paulo (Medical School of São Paulo). It was named in 1923 as Institute of Hygiene, and reorganized in 1931. When the works of the current headquarters (partnership between the Government of São Paulo and the Rockefeller Foundation) were completed, it became known as the Institute of Hygiene and Public Health, and remained as a department of the Medical School of São Paulo until 1945. Afterwards, it became an autonomous institute (the current School of Hygiene and Public Health, now the Faculdade de Saúde Pública (Public
Health School) of the Universidade de São Paulo (FSP-USP) ${ }^{11,13}$. In the same period, the Brazilian Nursing presented important movements for the consolidation of the professional category. In 1923, the School of Nursing of the Brazilian Department of Public Health (DNSP - Departamento Nacional de Saúde Pública) was created in Rio de Janeiro State, symbol of modern Nursing. Three years later, by Decree 17.268, dated March 31, 1926, the school was renamed Escola de Enfermeiras D. Anna Nery, considered official in Brazil through Decree 20,109 of 1931, as a standard of equivalence for the rest schools until the year 1949, with Law 775/49. 1926 was also marked by the founding of the Associação de Enfermeiras Diplomadas (Association of Graduate Nurses), the current Associação Brasileira de Enfermagem (ABEn) ${ }^{14,15}$.

In São Paulo, since the beginning of the $20^{\text {th }}$ century and reproducing the movements of the category at the national level, the nursing practiced, for the most part, by hands-on nurses, gradually promoted training initiatives based on modern nursing. For example, the Nursing Course of the Hospital Samaritano (1894), the Nursing Course of the Hospital São Joaquim (1908) and the Nursing Course of the Red Cross (1912) ${ }^{16}$. The aforementioned courses preceded the foundation of the first Escola de Enfermeiras (Nursing School) of the Hospital São Paulo (EEHSP), with activities started on March 1, $1939^{17}$.

Thus, considering the reverberation of the impact of this nationwide conflict, in addition to the mobilization of São Paulo society, above all by the accomplishment of the numerous courses of civil training in "hands-on nurses" for direct care for the wounded, especially promoted by the Institute of Hygiene, which at that time sought its affirmation as an educational institution, in the same way that the Brazilian and São Paulo Nursing struggled to assert itself, was questioned: "How was the Institute of Hygiene's performance in the training of "emergency nurses" during the Brazilian Civil War?"

The initiative of the study was supported by three perspectives: 1-The documentation's novelty, despite the few competent studies in which the Nursing work in the Brazilian Civil War was analyzed, was analyzed, there were no available studies that approached the specific phenomenon proposed here ${ }^{9,10,18}$; 2- The currentness and magnitude of the issue, since wars, whether world wars ${ }^{19}$ or civil wars, the latter usually stemming from internal conflicts in several countries, are constant objects of investigation. Especially because such conflicts, throughout history, have made hundreds of thousands of victims around the world; 3 - Necessity of the historical rescue of fragments related to the formation of the São Paulo Nursing identity and its institutional relations, from the beginning of the $20^{\text {th }}$ century ${ }^{16}$.

Therefore, the objective of the present study was to describe and analyze the Institute of Hygiene's performance in the training of "emergency nurses" during the Brazilian Civil War.

\section{METHOD}

This is a descriptive, historical-documentary study of a qualitative approach. Studies that use the qualitative method 
are understood here as those that deal with the subjective and relational level of social reality, being treated in the perspective of history, the universe, meanings, motives, beliefs, values and attitudes of social actors ${ }^{20}$.

The research shares the thought that the study of the past is only relevant when it is in the service of the present, so much that we have sought support in the theoretical framework proposed by Breih ${ }^{21}$, especially considering that historical research must propose a re-reading of advances of sciences of health and the individual and collective contributions of its actors.

The documentary corpus researched is part of the "Collection of the Revolution of 1932", which compiles the collection of the Centro de Memória da Saúde Pública da Faculdade de Saúde Pública da Universidade de São Paulo (Center for Memory of Public Health of the School of Public Health of the Universidade de São Paulo), dated July 13, 1932 and August 25, 1965. After formalization of the institutional authorization, all 420 documents of the collection were submitted to digitalization and organization in a digital database, which allowed instant access to each digitalized document.

Then, the pre-analytical procedure was started with the individual reading of the entire digitized collection and final selection of 92 documentary pages, which, in consensus, the three researchers judged to be pertinent in relation to the circumstances that involved creation, and later developments of the Emergency Nursing Course.

After selecting the 92 documents, participants characterization of this course began through application of relative frequency and absolute values. Then, the qualitative analysis was started, in which excerpts were selected, following criteria of pertinence and similarity, allowing the findings to be organized, categorized, described and discussed based on relevant and available scientific literature.

As it is a research with documentary sources available, it was not necessary to submit the project to the evaluation of the Committee of Ethics in Research with Human Beings ${ }^{22}$. However, it was decided to preserve the secrecy regarding identity of participants of the course, using abbreviations in front of excerpts that mentioned full names of participants.

\section{RESULTS}

\section{Efficient Nurse Collaborators - the profile of volunteers}

Emergency Nursing Course classes, also called War Nursing Course, started and finished between July 13 and August 31, 1932, and were organized by the Institute of Hygiene of São Paulo. The course was taught at the Institute of Hygiene, in five editions ( $1^{\text {st }}-$ July 13 to July 22; $2^{\text {nd }}$ - July 18 to August $2 ; 3^{\text {rd }}$ July 27 to August $5 ; 4^{\text {th }}$ - August 8 to August 17 ; and $5^{\text {th }}$ - August 22 to August 31), with an average of ten days of classes, from 09:00 to $11: 30$ and from 14:00 to 17:00. There was exception on weekends, with classes formed as participants were voluntarily recruited by Cruzada Pró-Infância (Childhood Crusade), Justice Battalion, Medical School of São Paulo, and Institute of Hygiene.
In addition to the numerous volunteer lists, the press collaborated in the mobilization and naturalization of transformation of civilians into war nurses. As they romanticized such practice, they also legitimized it, divulging it as essential to reach the aspirations proposed by São Paulo, as the excerpt below:

"No one is ignorant of what the nurse represents in a blood hospital on a battlefield. Her humane and unhappy work in caring for wounded soldiers, their self-denial and heroism for almost at times even gives life; all of this makes nurses the most efficient contributors to the victory of a cause."23:1

Thus, 383 students enrolled in the five editions of the course $\left(1^{\text {st }}-106,2^{\text {nd }}-100,3^{\text {rd }}-87,04^{\text {th }}-56\right.$ and $\left.5^{\text {th }}-34\right)$, the majority composed of women that is $312(81.5 \%)$, with a mean age of 26 years, a mode of 21 years old. The youngest was 14 years old, she a student of the first course, while the oldest, 52 , was a seamstress and student of the third course.

The most common occupations performed by these students were related to domestic service, being more frequent in the third course, represented by $35(49.3 \%)$ of the 71 female students. Teaching was the second most common profession, in general, being more frequent among students of the first course represented by $25(24.3 \%)$ of all 103 women enrolled. Other students were dentists, typists and civil servants. Two employees of Instituto do Café de São Paulo obtained authorization to participate in the $2^{\text {nd }}$ edition of the course, issued by the president of the aforementioned organ, as described below:

"We acknowledge receipt of your letter no. 58, dated 19th of this year, in reply to which we are pleased to inform you that, in response to your request, the President has agreed to waive their duties at these Institutes, Miss M.A.A.M and N.O.C, in order to be able to follow the nursing course of that institution. Sincerely yours."24:1

As for the 71 (18.5\%) men enrolled in the course, participation gradually increased, but remained discreet, reaching balance in its latest version, since in the first edition were enrolled $03(2.8 \%)$, in the second $13(13 \%)$, third $16(18.4 \%)$, fourth $22(39.3 \%)$ and fifth $17(50 \%)$. Most of the men were merchants, as well as some students from the Medical School of São Paulo, such as the case of two 20-year-old students attending the fifth edition.

After defining the classes that would compose each edition of the course, theoretical and hands-on classes were subsequently started, following a pre-defined standardized program content divided into two parts, the first one related to seven disciplines predominantly biological and the second strictly nursing, which will be described below.

\section{Epidemiology of war - the troop's health is the guarantee of victory}

Disciplines of the first part of the content were taught by 
professors of the Institute of Hygiene, as follows: 1 - Notions of Anatomy and Physiology, by Dorival Fonseca Ribeiro and José Maria Gomes; 2 - Notions of Bacteriology and Immunology, by Lucas Assumpção, Francisco Borges Vieira; 3 - Notions of Histology, by Otávio A. Rodovalho and Moacir Amorim; 4 - Notions of Pathology, by José Maria Gomes, John Lane, Otavio Guimarães Silva and Ulhôa Cintra; 5 - Epidemiology of War, by Francisco Borges Vieira; 6 - Hospital Dietetics, by Ulhôa Cintra and 7 - Qualitative Urine Examination, by Gastão Fleury da Silveira and Alexandre Wancolle.

The discipline Epidemiology of War, elaborated and taught by Francisco Borges Vieira, deserves to be highlighted by its originality in the singular context of the course. It sought to disseminate a hygienist conception of intervention (military hygiene), whose classes were divided into three subcategories (1 - Epidemiology and Communicable Diseases, 2 - Military Recruitment and Sanitation, and 3 - Sanitation of Facilities). Francisco Borges Vieira proposed a hygiene interface with the battlefield and his fighters, since he considered that "The troop's health is the guarantee of victory"25:3.

The first subcategory emphasized issues related to the history of world wars, etiology of communicable diseases, individual and general prophylaxis, transmitting animals (mosquitoes, fleas, ticks, bedbugs, flies, rats, dogs and horses) and the main diseases that would affect the troop, as pointed out in the quotation below:

\begin{abstract}
"In all meetings of men, the spread of epidemic diseases becomes easier, thanks to several factors. This danger in time of war is much greater than in times of peace. All troops who fought at the beginning of this century saw the armies decimated by diseases, such as exanthematic typhus, smallpox, cholera, plague, typhoid, disintegrates, etc., with their victims being often superior to those produced by wounds."25:1
\end{abstract}

The second subcategory addressed concepts of recruitment and sanitation of the troop, such as ideal selective measures (age, height, weight, chest perimetry, vision, hearing), physical and mental examination, personal hygiene rules, bathing and dressing military), bowel care, health education, soldiers' nutrition, physical exercises and walking (feet, heart, work in progress), illustrated by the excerpt below:

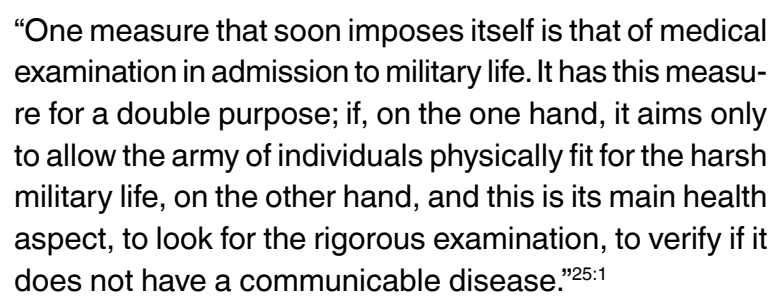

The third subcategory emphasized issues of sanitation of facilities such as tents, barracks, camps, trenches and blood hospitals, which contained rules to be adopted by soldiers for water intake, waste treatment destinations, human excreta and animals, as well as rules on the proper preparation of emergency facilities, taking into account the knowledge of characteristics related to humidity, ventilation, dust and confinement conditions, as mentioned below:

"One of the factors of disease spread in armies, as we said at the outset, is the crowding, overcrowded accommodations, which make the possibility of transmission closer. Therefore, sanitation should not be neglected due to the convenient destination of feces and urine, disinfection of drinking water, constant removal of waste that attracts flies, also disseminating."25:2

Also worthy of mention is the discipline called Notions of Pathology, which contemplated teaching exclusively to male students, about notions of prophylaxis of venereal diseases, with a hands-on internship followed by Professor José Maria Gomes at the Associação Comercial de São Paulo (Commercial Association of São Paulo).

\section{War Nursing}

War Nursing had nine subcategories of content, taught by nurse Iracema Niebler, who was aided by teaching supervisors, such as Maria Rosa de Sousa Pinheiro, Grasiela Marques Leite, Noêmia Ippolito, among others (Figure 1). According to the ima$\mathrm{ge}$, in the facilities of the Institute of Hygiene, Iracema Niebler, uniformed as a "registered nurse", taught a nursing technique class, handling a mannequin to a room full of students, aided by three monitors dressed in white (standing), one at the left end, the other at the center and another at the right end of the image.

It follows all nine subcategories of the War Nursing: 1 - General nursing (transportation, bed arrangement, bed nursing); 2 - Nursing technique (pulse, thermometry, blood pressure and graph filling); 3 - Medical nursing technique (subcutaneous/ intramuscular/intravenous injections and stomach pumping); 4 - Surgical nursing (surgical syndromes, emergency operating room, sterilization: asepsis and antisepsis. General/spinal/local anesthesia); 5 - Surgical material; 6 - Bandages and patches; 7 - First aid to the injured of trench; 8 - Pre and post-operative care; 9 - Postoperative complications (shock, internal and external hemorrhage, peritonitis, intestinal obstruction and signs of imminent death).

In the seventh subcategory, First Aid to the Wounded in the Trenches, the general rule was to deal with all types of injuries, as well as specific measures for various types of injuries such as head, chest, abdomen, lower limbs and fractured upper limbs exposed. In situations of injury to lower limbs with exposed fractures, it was advised to follow the general rule for all wounding and taping, immobilizing limbs with improvised triangles or splints (tree branches, etc.) and providing water and food at will to the injured. 
Figure 1. Nursing Hands-On Class of the Emergency Nursing Course. São Paulo, 1932. Source: Centro de Memória FSP-USP

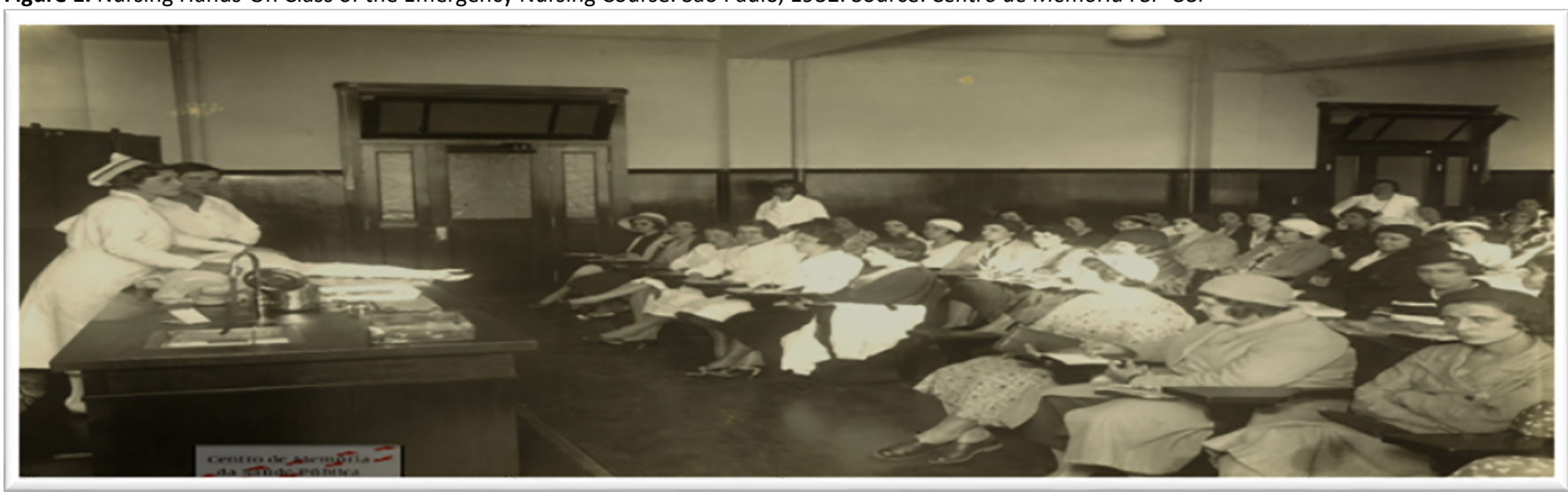

The topic "hemorrhage" was classified in the classes as internal and external, of arterial, venous or capillary origin, always oriented that during the period of external hemorrhagic events should perform indirect compression with a garrote or tourniquet, which should be improvised with stone, bandage, brace, triangle, a pencil or a plump stick.

In addition to the theoretical description, there were drawings that carefully illustrated first aid techniques (Figure 2), to be performed by war nurses, which included presentation of cotton-based materials to be used (patches, triangles, bandages), besides different techniques of immobilization and compression of shoulder, skull, arm, buttocks and legs.

After completing the theoretical study, the hands-on internship began, which lasted an average of three days and was carried out in groups composed, on average, of ten students, who presented themselves systematically at Hospital Santa Catarina, Hospital Alemão, Santa Casa de Misericórdia and at the Polyclinic. At the end of the internship, a final exam was carried out to evaluate the performance of the students, who subsequently graduated in formal ceremony at the Institute of Hygiene, as can be seen below:

"Yesterday at the São Paulo Institute of Hygiene the ceremony of oath and certificate delivery to the $3^{\text {rd }}$ group of girls and boys who attended the Emergency Nursing Course, taught by that institution, was held yesterday at the Institute of Hygiene of São Paulo. Professor Paula Souza, Director of the Institute, opened the session, which gave the floor to the chief's nurse, Dr. Iracema Niebler, who with words of exalted civility and brasilidade, exhorted the new nurses to good practice, assisting wounded or civilian soldiers who lacked them, and pointed out to them the heroic figures of Anna Nery, who provided such excellent services in the campaign of Paraguay and patroness of the Brazilian nurses and Florence Nightingale, the "lamp lady" of the Crimean War."26:1

In the ceremonies of diplomacy, the "Oath of the Emergency
Nurse", by Iracema Niebler: "Before God and the Nation, I swear to São Paulo, to carry out care with honor, nobility, dignity and loyalty, to the wounded Brazilian soldier on the battlefield and to the civilian who needs it."27:1 Once they graduated, the emergency nurses were able to provide assistance and were sent to the Paulista Barracks to compose the list of nurses, who would be headed by Dr. João Rebelo Neto, as well as the auxiliary doctors: Francisco Ourique, Passos Cunha, Honório Dias Soares and Faustino Ferreira Gomes.

Many of the registered nurses worked during the conflict, so much so that the São Paulo Defense League, on September 24, through a formal document sent to the General Superintendency of Transportation, stated that one of the former students was providing assistance services to soldiers. Soon, his family needed authorization for free transit of official cars. Other evidences of the unfolding of the performance of these participants can be verified through the evidence of participation in the course under analysis, formally issued by the Directors of the Institute of Hygiene after the year 1948, as can be seen in the following excerpt:

"I certify, for the due purposes, that Miss O.R.B followed the $3^{\text {rd }}$ War Emergency Nursing Course, carried out by the former Institute of Hygiene of São Paulo, during the Constitutionalist Revolution of 1932, as recorded in the archives of that division, having afterwards, the Hospital "Alemão", today called "Oswaldo Cruz", and later to the Santa Casa de Misericórdia (Blood Section where the wounded from the near front of the capital were transported), in order to lend the nursing services." $28: 1$

\section{DISCUSSION}

The course under analysis legitimized the ideological alignment of the Institute of Hygiene, which struggled to assert itself autonomously in the field of health education with the interests of the government and the São Paulo elite. This movement took place against the interests of the Provisional Government, given the relevant link between the Institute and the Faculty of Medicine of São Paulo, and the first, from its foundation to the year 
Figure 2. Illustrations of the Discipline "First Aid to the Wounded in the Trench" of the Emergency Nursing Course. São Paulo, 1932. Source: Centro de Memória FSP-USP

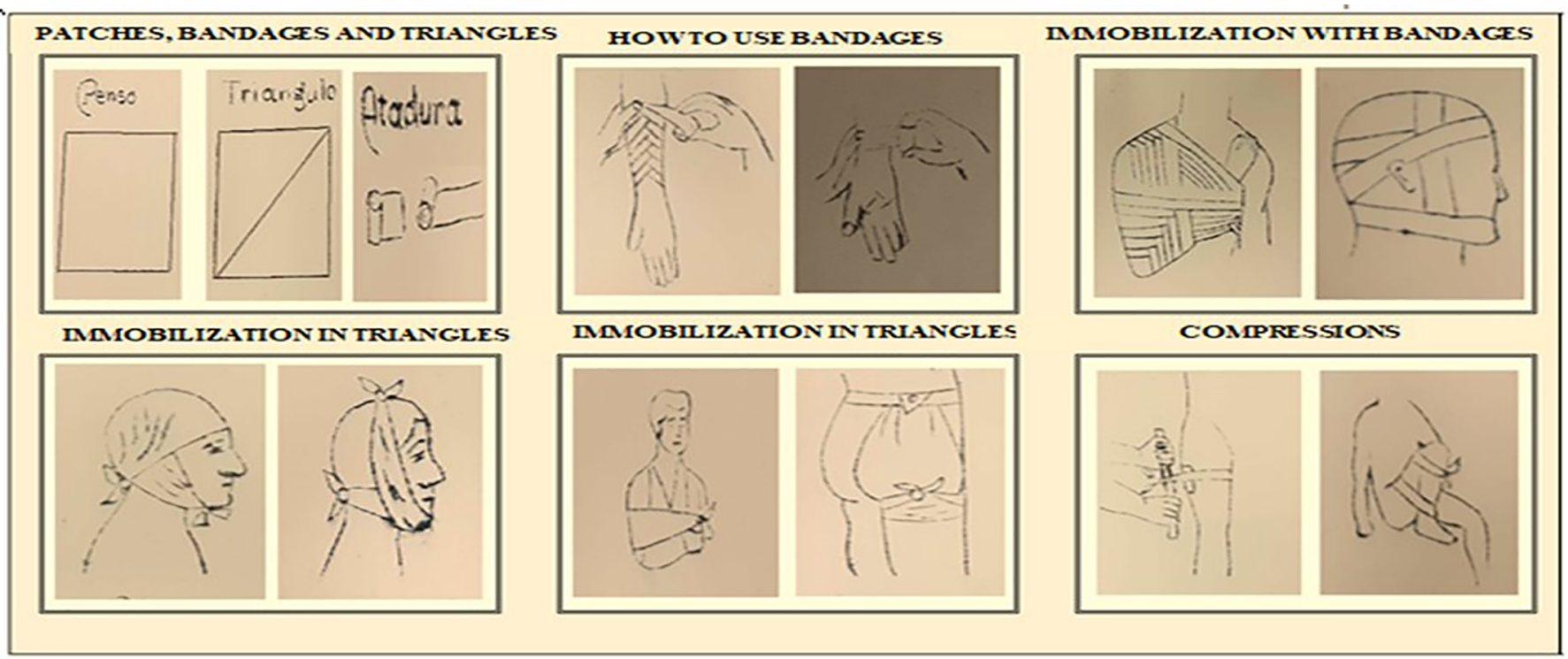

1924, served as a section of the latter, which for his part, was a convinced oppositionist of the Government of Getúlio Vargas ${ }^{29}$.

It was crucial for São Paulo, especially for the fragility of the insurgents, to bring together as many volunteers as possible. In a single combat front of the South, the difference was of ten thousand men in favor of the federal troops, besides the relation of distribution of automatic weapons of war, one for each 03 federal soldiers, against one for each 50 soldiers of São Paulo ${ }^{3}$.

Thus, volunteers were recruited through organized civil groups, such as the Childhood Crusade, the Liga das Senhoras Católicas (freely translated as Catholic Ladies League), the Justice Battalion, the Medical School of São Paulo, the Institute of Hygiene, etc., which promoted the enlistment and provided food and lodging for. ${ }^{3}$ It is mentioned that advertising strategies, with focus on the mobilization and recruitment of volunteers, were implemented by the mass media to the elitist. Strategies based on the discourse of authority, competence and paulistanidade $^{5}$, so much that one of the most publicized posters was of a solemn nurse, with the left finger cocked, right hand on the thorax (left side), that said: "Paulista: I've already done my duty. What about you?".

The Civil Enlistment and Propaganda Department used the press as an ally, extolling the social role of the nurse figure, sensitizing civilians in order to transform them into war nurses, especially considering that the owner of the newspaper O Estado de S. Paulo, Júlio de Mesquita Filho, was one of the enthusiasts of press engagement in the $1932 \mathrm{War}^{3}$.

In the face of the numerous training initiatives of war nurses (Blue Cross, Red Cross, Black Legion, etc.), it is considered that the course of the Institute of Hygiene trained a considerable number of hands-on nurses. Especially when compared with the group of 168 volunteers from the Provisional Government who held the "First Aid and Hands-On Nursing Course", given by the EEAN during the same conflict ${ }^{18}$.
Despite being a hands-on course, there was a notable female participation, that is, $308(81.2 \%)$, a trend observed even on other voluntary fronts, such as the participation of 70,000 women in sewing workshops ${ }^{5}$, as well as numerous volunteers linked to Blue Cross, who worked on the delivery of medicines to the homes of the wounded of war and services of correspondence/ information between combatants and their relatives ${ }^{3}$.

Although the training in Emergency Nursing allowed ruptures in the traditionalist and paternalistic discourse that affirmed the place of the woman, it contributed to keep it within the frame of the supposed natural vocation for the profession ${ }^{30}$, and naturalized the woman-care relationship. Such a statement is made because the State could name the course only as a "hands-on course of lifeguards" and accept volunteers of both genders, but preferred to use the archetype of the "nursing profession", although it faced an imagistic-discursive structuring, above all by the institutionalization of education (Decree 20,109, June 15, 1931) and adherence to new concepts, was permeated by eugenic and elitist influences, so much so that admission to official nursing schools was hegemonically white and favored social strata ${ }^{9,31}$.

The performance of the five courses with training of hundreds of "war nurses", between July 13 and August 31, was a shocking event in the process of legitimacy of the Institute of Hygiene against the society and medicine of São Paulo. The fact that the first course began after only five days of the outbreak of armed conflict, according to the documentation researched, a process of organization, both of institutional structure and of highly complex pedagogical and scientific contribution, demonstrates a mobilization that preceded the beginning of the war of 1932. According to the documentation researched, it is questioned: Was there a prior planning for a fully structured course, with teaching staff and teaching aides, as well as meticulously organized theoretical and hands-on content?

The research seems to point to a positive response, as well 
as to the previous non-disclosure, considering the knowledge of information and actions that, known to the opposing side, could anticipate reprisals or even an armed invasion.

Disciplines of the first part of the content introduced students into concepts of Medical Science, with an emphasis on hygienist conception, permeated by knowledge of Physiology, Microbiology, Histology and Pathology, where, with due proportions, they resembled the courses taught to educators by that Institute from 1926 onwards $^{29}$. The same happened, considering the grade of disciplines of Emergency Nursing, taught by Blue Cross, under the leadership of Professor Raul Briquet, who approached notions of Surface Anatomy, Bacteriology, Elementary Medical Nursing, Surgical Nursing, Pathology and First Aid to the Wounded ${ }^{3}$.

Classes of Venereology, exclusive to men, as advocated, can be justified by the high prevalence of syphilis, as well as other venereal diseases (soft cancer, gonorrhea, among others) in that period, being one of the diseases that most affected the fighters in the trenches of the 1932 war $^{5}$. Since the 1910s, in the Navy of Brazil, educational and prophylactic measures were disseminated in order to combat this aggravation, considered a hindrance to the project of a modern Brazilian nation that craved ${ }^{32}$.

In Epidemiology of War, it was identified the influence of hygienist concepts and disciplinalization of bodies ${ }^{33}$, purposely prepared by Francisco Borges Vieira, professor responsible for the Epidemiology section of the Institute of Hygiene and who, since 1931, was the Director General of the State Service Sanitary. Throughout his career, he published numerous epidemiological studies, including with Gastão Fleury da Silveira, also professor of the course under analysis ${ }^{29,34}$.

Nursing disciplines focused on exposing concepts and information for the training of exclusively hands-on workforce, so that students would be able to work in field hospitals, being strictly enforcers of basic techniques, besides procedures related to hygiene, handling and care of surgical materials. As well as actions related to patient care in situations of imminent risk of death, usually undergoing surgical procedures, and injured in the trenches, as illustrated by Figure 2.

The participation of Iracema Isabel Niebler, a nurse trained by the EEAN, linked to the Institute of Hygiene since the early 1930s, was outstanding, since she taught in many other courses carried out by the institution, such as those of health educators, being, until the year 1949, responsible for supervising them ${ }^{35}$. Among the teaching assistants, stands out Maria Rosa de Sousa Pinheiro, a Sanitary Educator graduated from the Institute of Hygiene in 1930, graduated in Nursing (1944), in Toronto, Canada, taking the position of Director of the School of Nursing at the Universidade de São Paulo in $1955^{36}$.

The accomplishment of the hospital hands-on internship as the last requisite before the conclusion of the course, besides allowing the performance of theoretical knowledge learned, also sought to accustom students with that space of care, where they would probably act, whether in the capital or in the countryside. Public and private hospitals, in every state of São Paulo, had about 2,000 beds to care for the wounded, which, at first, might seem to be sufficient. However, in comparison with the number of hospital visits in the North Front trenches, it seems to have been insufficient, since, according to some sources, 1,006 hospitalizations were carried out during the conflict, of which 588 were wounded, including 77 wounded by grenade and 75 by firearms ${ }^{3}$.

At the end of the training, the graduation ceremony of students, the oath, seems to have been a request of Iracema Niebler, mainly for being a nurse graduated by EEAN. Emblems and rituals (headdress, veil, lamp pass, oath, etc.), along the history of Brazilian Nursing History, were part of the daily life of educational institutions, supposedly under religious and military influence, in order to transmit and reinforce predicates such as hierarchy and discipline ${ }^{37}$.

This study, even with the limit imposed by the researched documentation, especially regarding the setting of effective participation of emergency nurses in caring for wounded on the battlefield (post-training), pointed to a training process of success in front of the institutional project. Some records allowed approximations to this question, mainly due to the high number of requests and certifications of proof of participation in the course under analysis issued after 1948.

Requests were motivated by the interest of instructing cases addressed to the Committee on Article 30 of the Transitory Provisions of the State Constitution, dated July 9, $1947^{38}$ mainly after 1948, when Law 211 of December 7, 1948 was sanctioned. This Law regulated the advantages granted by the aforementioned Article 30 Commission to the active participants of the Constitutionalist Revolution of 1932, which included preference for entry into the public service, internal promotion to public officials, donation of lots of up to 50 hectares for those who wished to dedicate themselves to activities rural areas, among others ${ }^{39}$.

\section{CONCLUSION AND IMPLICATIONS FOR THE PRACTICE}

The execution of the War Nursing course, carried out by the Institute of Hygiene, characterizes its participation in the Brazilian Civil War. The performance in the preparation of volunteers exposed its position of alliance to the movement and the institutions of the São Paulo science, besides legitimizing and strengthening its role in the training of health professionals included in the modernization project of São Paulo.

Although the course started its activities during the conflict, it is believed that there was a planning about its accomplishment, that was conditioned to the outbreak of the conflict, given to the logistics, personnel mobilization and structuring of theoretical and hands-on content.

The state of São Paulo used nursing (a profession that began to assert itself in that period) as a mechanism for institutionalizing and rationalizing care practices necessary for its effective combatants and civilians, allowing students, typists, housewives, etc., were "mobilized by civic duty" and transformed into "war nurses". It is not wrong to say that such an initiative contributed to affirmation of the profession in the midst of the' São Paulo society. 
Considering gender inequality in access to education and training, the superiority of female participation points to a way for women, especially young women, to leave home and participate in the war, to learn a profession while exercising the civic duty acclaimed in advertisements for the mobilization of volunteers.

The course's repertoire had varied and well-structured content divided into two main axes, being a pedagogical strategy necessary, given the short time and profile of the students. The presence of the hygienist paradigm, evident in the discipline called "Epidemiology of War" and the participation of Francisco Borges Vieira.

It is worth noting the presence of a nurse as professor responsible for teaching a nursing's discipline, with emphasis on "First Aid to the Wounded in the Trenches". Although such content was part of a hands-on and rapid course, it is not an exaggeration to consider that it was a faithful example of the first initiatives of teaching and first aid of the Brazilian nursing in emergency situations.

Despite all limitations pointed out previously, the documentation studied allowed a first approximation of the theme, fulfilling its initial proposal of contribution by rescuing the memory of the Institute of Hygiene and of nursing in the Brazilian Civil War. That was a contribution that could be added to the approaches on nursing performance in situations of conflicts, mass violence, catastrophes and wars in different historical times, especially nowadays.

Other issues emerged from the documentation studied, pointing to future works, among them the understanding of how "nurses" trained by the Institute of Hygiene or other institutions were allocated on battle fronts by the state of São Paulo and how they acted in caring for the wounded during the 85 days of conflict of the Brazilian Civil War.

\section{REFERENCES}

1. Ribeiro FC. A historiografia da Guerra de 1932 e a sua amplitude. Mosaico [Internet]. 2017 Jun; [cited 2018 Jun 15]. 8(12):226-47. Available from: http://bibliotecadigital.fgv.br/ojs/index.php/mosaico/ article/view/65514/66868

2. Fausto B. A revolução de 1930: História e historiografia. São Paulo: Companhia das Letras; 1997.

3. Rodrigues JP. Levante "Constitucionalista" de 1932 e a força da tradição. Do confronto bélico à batalha pela memória (1932-1934) [tese]. Assis (SP): Universidade Estadual Paulista Júlio de Mesquita Filho, Programa de Pós-Graduação em História; 2009.

4. Villa MA. 1932: Imagens de uma Revolução. São Paulo: Imprensa Oficial do Estado de São Paulo; 2008.

5. Santos MAC, Mota A. São Paulo 1932: memória, mito e identidade. São Paulo: Alameda; 2010.

6. Pandolfi D. Os anos 1930: as incertezas do regime. In: Ferreira J, Delgado LAN, orgs. O Brasil Republicano II - O tempo do nacionalestatismo: do início da década de 1930 ao apogeu do Estado Novo. Livro II. Rio de Janeiro (RJ): Civilização Brasileira; 2003.

7. Donato H. História da Revolução de 1932. São Paulo: IBRASA; 2002.

8. Horta MCAL, Maurícia F, Lauar SO, Gouveia TR. A Revolução de 1932 sob o olhar do Parlamento Paulista. Acervo Histórico [Internet]. 2016 Jul; [cited 2018 Jun 17]; 2(7):1-22. Available from: https://www.al.sp. gov.br/acervo-historico/publicacoes/Informativos/informativo_0007.pdf
9. Campos PFS. As enfermeiras da Legião Negra: representações da enfermagem na revolução constitucionalista de 1932. Faces de Eva. Estudos sobre a Mulher [Internet]. 2015 Jun; [cited 2018 Jun 17]; 33:53-65. Available from: http://www.scielo.mec.pt/scielo. php?script=sci_arttext $\&$ pid=S0874-68852015000100007

10. Löw L. Enfermeiras Negras na Revolução Constitucionalista de 1932 [dissertação]. São Paulo (SP): Escola de Enfermagem da Universidade de São Paulo; 2013.

11. Lima NT, Fonseca CMO. História da especialização em saúde pública no Brasil: nota introdutória. In: Lima NT, Fonseca CMO, Santos PRE, orgs. Uma escola para a saúde. Rio de Janeiro (RJ): Editora Fiocruz; 2004.

12. Santos PS. Cinquentenário da Faculdade de Saúde Pública da USP. Rev Saúde Pública [Internet]. 1975 Jun; [cited 2018 Jun 17]; 9(2):957. Available from: http://www.scielo.br/scielo.php?script=sci_arttext \&pid=S0034-89101975000200001. DOI: http://dx.doi.org/10.1590/ S0034-89101975000200001

13. Correia LC. Instituto de Higiene (1918-1929) no estado de São Paulo - a atuação de Geraldo Horácio de Paula Souza e Mário da Costa Galvão. Caderno de História da Ciência - Instituto Butantan [Internet]. 2011 Jun; [cited 2018 Jun 17]; 7(1):71-85. Available from: https://bibliotecadigital.butantan.gov.br/edicao/cadernos-dehistoria-da-ciencia-volume-7-numero-1-2011/70

14. Medeiros M, Tipple ACV, Munari DB. A expansão das escolas de enfermagem no Brasil na primeira metade do século XX. Rev Eletr Enferm [Internet]. 1999 Oct/Dec; [cited 2018 Jun 17]; 1(1). Available from: https://www.revistas.ufg.br/fen/article/view/666/736. DOI: https://doi.org/10.5216/ree.v1i1.666

15. Pereira Neto AF. Interfaces da história da Enfermagem: uma potencial agenda de pesquisa. Esc Anna Nery [Internet]. 2006 Dec; [cited 2018 Jun 17]; 10(3):524-31. Available from:http://www.scielo. br/scielo.php?script=sci_arttext\&pid=S1414-81452006000300023. DOI: http://dx.doi.org/10.1590/S1414-81452006000300023

16. Mott ML. Revendo a história da enfermagem em São Paulo (18901920). Cad Pagu [Internet]. 1999; [cited 2018 Jun 17]; (13):327-55. Available from: https://periodicos.sbu.unicamp.br/ojs/index.php/ cadpagu/article/view/8635331/3133

17. Silva MRG, Gallian DMC. A Escola de Enfermagem do Hospital São Paulo e seu primeiro currículo (1939-1942). Rev Bras Enferm [Internet]. 2009 Mar/Apr; [cited 2018 Jun 17]; 62(2):31722. Available from: http://www.scielo.br/scielo.php?script=sci arttext\&pid=S0034-71672009000200024\&Ing=pt\&tlng=pt

18. Almeida Filho AJ, Santos TCF. Participação da escola Anna Nery na revolução constitucionalista de 1932. Rev Bras Enferm [Internet]. 2003 Oct; [cited 2018 Jun 17]; 56(5):581-5. Available from: http://www.scielo.br/scielo.php?script=sci_arttext\&pid=S0034$71672003000500024 \&$ Ing=en\&nrm=iso. DOI: http://dx.doi. org/10.1590/S0034-71672003000500024

19. Kneodler TS, Paes GO, Porto FR, Nassar PRB, Oliveira AB. A enfermagem em tempos de guerra: propaganda política e valorização profissional (1942-1945). Rev Bras Enferm [Internet]. 2017 Apr; [cited 2018 Jun 17]; 70(2):407-14. Available from: http:// www.scielo.br/pdf/reben/v70n2/pt_0034-7167-reben-70-02-0407. pdf

20. Minayo MCS. O desafio do conhecimento: pesquisa qualitativa em saúde. São Paulo: Hucitec; 2013.

21. Breilh J. Espejo, adelantado de la ciencia crítica: una "antihistoria" de sus ideas em salud. Quito: Corporación Editora Nacional; 2016.

22. Conselho Nacional de Saúde (BR). Resolução № 466, de 12 de dezembro de 2012. Trata de pesquisas em seres humanos e atualiza a resolução 196. [Internet]. Diário Oficial da União. 2012 Out [cited 2018 17]; Available from: http://conselho.saude.gov.br/ resolucoes/2012/Reso466.pdf

23. Coletânea da Revolução de 1932: Cópia do Jornal "A Gazeta"; Pasta 1 - MI.11:01 (Centro de Memória da Saúde Pública da Faculdade de Saúde Pública da Universidade de São Paulo). São Paulo; 1932. 
24. Coletânea da Revolução de 1932: Declaração de Dispensa do Instituto do Café do Estado de São Paulo. Pasta 3 - SC. 06:01 (Centro de Memória da Saúde Pública da Faculdade de Saúde Pública da Universidade de São Paulo). São Paulo; 1932.

25. Coletânea da Revolução de 1932: Noções de Epidemiologia de Guerra; Pasta 1 - Ml.09:22 (Centro de Memória da Saúde Pública da Faculdade de Saúde Pública da Universidade de São Paulo). São Paulo; 1932.

26. Coletânea da Revolução de 1932: Relatório do Curso de Enfermagem de Emergência. Pasta 3-SC.21:01 (Centro de Memória da Saúde Pública da Faculdade de Saúde Pública da Universidade de São Paulo). São Paulo; 1932.

27. Coletânea da Revolução de 1932: Juramento da Enfermeira de Emergência; Pasta 1 - MI.05A:01 (Centro de Memória da Saúde Pública da Faculdade de Saúde Pública da Universidade de São Paulo). São Paulo; 1932.

28. Coletânea da Revolução de 1932: Certificado de Participação no Terceiro Curso de Enfermagem de Emergência. Pasta 4 - TC. 25C:01 (Centro de Memória da Saúde Pública da Faculdade de Saúde Pública da Universidade de São Paulo). São Paulo;1950.

29. Candeias NMF. Memória histórica da Faculdade de Saúde Pública da Universidade de São Paulo -1918-1945. Rev Saúde Pública [Internet]. 1984 Dec; [cited 2018 Jun 17]; 18(no.spe):2-60. Available from: http://www.scielo. $\mathrm{br} /$ scielo.php?script=sci_arttext\&pid=S0034-89101984000700002\&lng=e n\&nrm=iso. DOI: http://dx.doi.org/10.1590/S0034-89101984000700002

30. Cytrynowicz R. A serviço da pátria: a mobilização das enfermeiras no Brasil durante a Segunda Guerra Mundial. Hist Ciênc Saude-Manguinhos [Internet]. 2000 Mar/Jun; [cited 2018 Jun 17]; 7(1):73-91. Available from: http://www.scielo.br/scielo.php?script=sci_arttext\&pid=S010459702000000200004\&lng=en\&nrm=iso. DOI: http://dx.doi.org/10.1590/ S0104-59702000000200004

31. Secaf V, Ethel O. Parsons. In: Costa HB, org. Elas Vieram de Longe. São Paulo: Martinari; 2010.

32. Machado GT, Ross S. Inimigas da pátria: Propostas educativas para a guerra contra as doenças venéreas na Marinha do Brasil nas décadas de 1920 e 1930. Sex Salud Soc [Internet]. 2018 Jan/Apr; [cited 2018 Jun 17]; 28:206-25. Available from: http://www.scielo.br/scielo.php?script=sci_ar ttext\&pid=S198464872018000100206\&lng=en\&nrm=iso26. DOI: http:// dx.doi.org/10.1590/1984-6487.sess.2018.28.11.a
33. Marques MCC, Brasileiro DF, Fernandes SCG. Informação e disciplina: a Coletânea de Educação Sanitária do estado de São Paulo, Brasil (1939-1952). Interface (Botucatu) [Internet]. 2017 Oct; [cited 2018 Jun 17]; 21(61):397-410. Available from: http://www.scielo.br/scielo. php?script=sci_arttext\&pid=S1414-32832017000200397\&lng=en\& nrm=iso. DOI: http://dx.doi.org/10.1590/1807-57622016.0100

34. Marques MCC, Dolci MC. Boletim e Arquivos: a comunicação científica até a criação da Revista de Saúde Pública Rev Saúde Pública [Internet]. 2016 Oct; [cited 2018 Jun 17]. 50:62. Available from: http://www.scielo.br/scielo.php?script=sci_arttext\&pid=S003489102016000100132\&lng=en\&nrm=iso. DOI: http://dx.doi. org/10.1590/S1518-8787.2016050000115

35. Takashi MH. Movimento da enfermagem paulista na década de 1940: reformulação do ensino profissional [dissertação]. São Paulo (SP): Escola de Enfermagem da Universidade de São Paulo; 2011.

36. Oguisso T, Campos PFS, Santiago ES. Maria Rosa Sousa Pinheiro e a reconfiguração da enfermagem brasileira. Texto Contexto Enferm [Internet]. 2009 Oct/Dec; [cited 2018 Jun 17]; 18(4):643-51. Available from: http://www.scielo.br/scielo.php?script=sci_arttext\&pid=S010407072009000400005\&lng=en\&nrm=iso. DOI: http://dx.doi. org/10.1590/S0104-07072009000400005

37. Toledo JR, Santos TCF, Araujo MA, Almeida Filho AJ. Emblemas e rituais: reconstruindo a história da Escola de Enfermagem Hermantina Beraldo. Esc Anna Nery [Internet]. 2008 Jun; [cited 2018 Jun 17]; 12(2):243-50. Available from: http://www.scielo.br/scielo. php?script=sci_arttext\&pid=\$1414-81452008000200007\&lng=en\&n rm=iso. DOI: http://dx.doi.org/10.1590/S1414-81452008000200007

38. Resolução - ALESP № 1, de 28 de março de 1947. Dispõe sobre o Regimento Interno da Comissão Especial de Constituição. 1947. [cited 2018 Jun 17]. Available from: http://www.al.sp. gov.br/repositorio/legislacao/resolucao.alesp/1947/resolucao. alesp-1-28.03.1947.html

39. Lei № 211 , de 7 de dezembro de 1948. Regulamenta as vantagens concedidas pelo artigo 30 do Ato das Disposições Constitucionais Transitórias aos participantes ativos da Revolução Constitucionalista de 1932. [cited 2018 Jun 17]. Available from: https://www.al.sp.gov. $\mathrm{br} /$ norma/31571 